\title{
Climate Change-Induced Agricultural Drought over Moist-Cool and Moist-Warm Climatic Zones: A Case Study in Ale and Adami-Tulu Woredas, in Oromia National Regional State, Ethiopia
}

\author{
Fedhasa Benti ${ }^{1 *}$ and Achalu Chimdi ${ }^{2}$ \\ ${ }^{1}$ Department of Environmental Science, College of Natural and Computational Sciences, \\ Wollega University, P.O. Box 395, Nekemte, Ethiopia; ${ }^{2}$ Department of Natural Resource Management, \\ College of Agriculture and Veterinary Science, Ambo University, P.O Box 19, Ambo, Ethiopia
}

*Corresponding author: fedeesa@gmail.com

\begin{abstract}
Frequency and intensity of drought have troubled sustainable agriculture and worsened food insecurity of Ethiopians. This study aimed to investigate climate change-induced agricultural drought over the moist-cool and moist-warm climatic zones, using historical precipitation and temperature data recorded in the crop growing months for 35 years. The changes of temperatures and precipitation were analyzed using Mann Kendall trend test. Agricultural drought indices were analyzed using R-model by withdrawing potential evapotranspiration from precipitation to determine the existing water balance. The values of drought indices were used to characterize the duration, severity, intensity and trends of agricultural drought. Results showed that the changes in maximum and minimum temperatures and precipitation were significantly stronger in the Ale Woreda $(\mathrm{P}<0.05)$. However, minimum temperature and precipitation in Adami-Tulu did not noticeably change. The spatial drought events occurred more widely in Ale than in Adami Tulu. The events occurred 12 and 17 times with cumulative severity indices of 41.95 and 48.22 in Ale and Adami-Tulu, respectively. Agricultural drought intensities of the two districts were labeled as "severe" and "moderate dry", for Ale and Adami-Tulu, respectively. The intensity of drought in Ale district significantly increased $(\mathrm{P}<0.05)$ and that in Adami-Tulu negligibly changed. Therefore, the study explicitly showed that more changes in temperature and precipitation aggravated agricultural drought in Ale than in Adami-Tulu more intensely and it is suggested that more attention shall be paid to Ale Woreda.
\end{abstract}

Keywords: agricultural drought, eco-climatic zones, climate change, potential evapotranspiration, precipitation, temperature

Cite this as: Benti, F., \& Chimdi, A. (2019). Climate Change-Induced Agricultural Drought over Moist-Cool and Moist-Warm Climatic Zones: A Case Study in Ale and Adami-Tulu Woredas, in Oromia National Regional State, Ethiopia. Caraka Tani: Journal of Sustainable Agriculture, 34(2), 188-199. doi: http://dx.doi.org/10.20961/ carakatani.v34i2.29344

\section{INTRODUCTION}

Climate change is regarded as a future potential threat that will influence sustainable agriculture. It intensifies hydrological cycle and evapotranspiration at local and global scales and will increase drought in the future; in particular, short-term drought will be more influenced by climate change (Lee et al., 2017). Drought is an abnormal part of the climate that can occur in any place and time and it is considered the most severe natural hazard (Svoboda and Fuchs, 2017). A greater proportion of the population in different parts of the world was affected more severely by drought than by other natural disasters. For

\footnotetext{
* Received for publication April 16, 2019

Accepted after corrections July 31, 2019
} 
instance, in Sahara desert of Africa, drought events account less than $20 \%$ of natural disasters, but account for over $80 \%$ of the affected population (United Nations, 2011). The disaster can have a substantial impact on ecosystems and many economic sectors, predominantly on agriculture and food security (Arndt et al., 2012). An unanticipated climate shocks may devastate herds and harvests, as well as threaten local food stocks. Related to drought event, a huge number people under starvation has been growing at an alarming rate in the world (Mahoo et al., 2013; Funk et al., 2018).

Ethiopia is one the most vulnerable countries facing challenges of drought due to its great reliance on climate vulnerable economy (Conway and Schipper, 2011). The pivotal position of agricultural economy in the total national economy is accounted 40.5 percent of Gross Domestic Product (GDP), 81 percent of exports and 85 percent of labor forces (MoFED, 2016). The current annual per capita of food supply in Ethiopia is estimated to $202.6 \mathrm{~kg}$, which is lower than the minimum world's food requirement threshold of $218 \mathrm{~kg}$ (Kedir et al., 2018). Furthermore, the adverse impact of drought on agriculture in the future may put the country food supply in a detrimental situation (FAO, 2012). The projected reduction in the Ethiopian agricultural productivity due to climate change can reduce average income by 30 percent over the next 50 years (Gebreegziabher et al., 2016). The changes of precipitation and temperatures trigger the prevalence of agricultural drought in Ethiopia. The frequency and intensity of drought events have disrupted crop production and worsened food insecurity of the country.

Ethiopian highlands move towards severe climatic shocks due to the higher human activity increases the exposure of agricultural sector to climate challenges. Therefore, understanding climatic variability and its association with extreme events (drought and excess rain) under different eco-climatic zones is important to identify areas vulnerable to climate shocks as well as to provide proper adaptation strategies. This is critical, particularly for academicians, politicians and agronomists to have strong awareness and to make proper decision on the future climate change related shacks. Consequently, several studies were conducted to assess climate change related shocks. For instance, Zerga and Mengesha (2018);
Arndt et al. (2012) had assessed climate variability and change, impact, mitigation and adaptation. However, all findings are largely aggregated and do not reveal the right magnitude and inherent capacity of agricultural drought at different climatic zones. Therefore, to overcome this problem, the study was conducted over the moist-cool zone and moist-warm zone.

\section{MATERIALS AND METHOD}

\section{Description of the study area}

Ale and Adami Tulu are two Woredas, located in the two different eco-climatic zones. According to Zerga and Mengesha (2018), Ale Woreda represented the moist-cool zone and Adami Tulu the moist-warm zone. Ale is located between $7^{\circ}$ $37^{\prime} 30^{\prime \prime}$ to $8^{\circ} 05^{\prime} 00^{\prime \prime} \mathrm{N}$ in latitude and $35^{\circ} 24^{\prime} 80^{\prime \prime}$ to $35^{\circ} 50^{\prime} 00^{\prime \prime} \mathrm{E}$ in longitude in Ilu Ababora zone. Its elevation is $1803 \mathrm{~m}$ a.s.l. and its average annual temperature and rainfall is $20^{\circ} \mathrm{C}$ and $2080 \mathrm{~mm}$, respectively. Adami Tulu Woreda is one located between $7^{\circ} 30^{\prime} 00^{\prime \prime}$ to $8^{\circ} 30^{\prime} 00^{\prime \prime} \mathrm{N}$ in latitude and $38^{\circ} 21^{\prime} 00^{\prime \prime}$ to $38^{\circ} 54^{\prime} 00^{\prime \prime} \mathrm{E}$ in longitude in the East Showa zone, Oromia regional state. Its annual average temperatures and rainfall are $21^{\circ} \mathrm{C}$ and $856 \mathrm{~mm}$ with $1645 \mathrm{~m}$ a.s.l elevation (Figure 1). According to the site map of Ethiopian treasure (n.d), the two woredas have four hydrological seasons in a year, namely autumn, winter, spring and summer. Autumn runs from September to November (SON) and it relatively wet, winter is dry season running from December to February (DJF), spring a rainy season that runs from March to May (MAM) and summer is the main rainy season or the main cropping season of the two districts that happens from June to August (JJA).

\section{Data collection}

Historical data of maximum and minimum temperatures and precipitation of the two zones, recorded from 1981 to 2016 during the main crop growing seasons (June to September), were obtained from NASA power data access viewer. They are gridded datasets of rainfall and temperature at $0.50 \times 0.50$-degree resolution.

\section{Data detection}

The missing values, outliers and autocorrelation and homogeneity tests were performed before data analyses to avoid the internal variation that could affect the absolute values of mean and standard deviation the variables. 


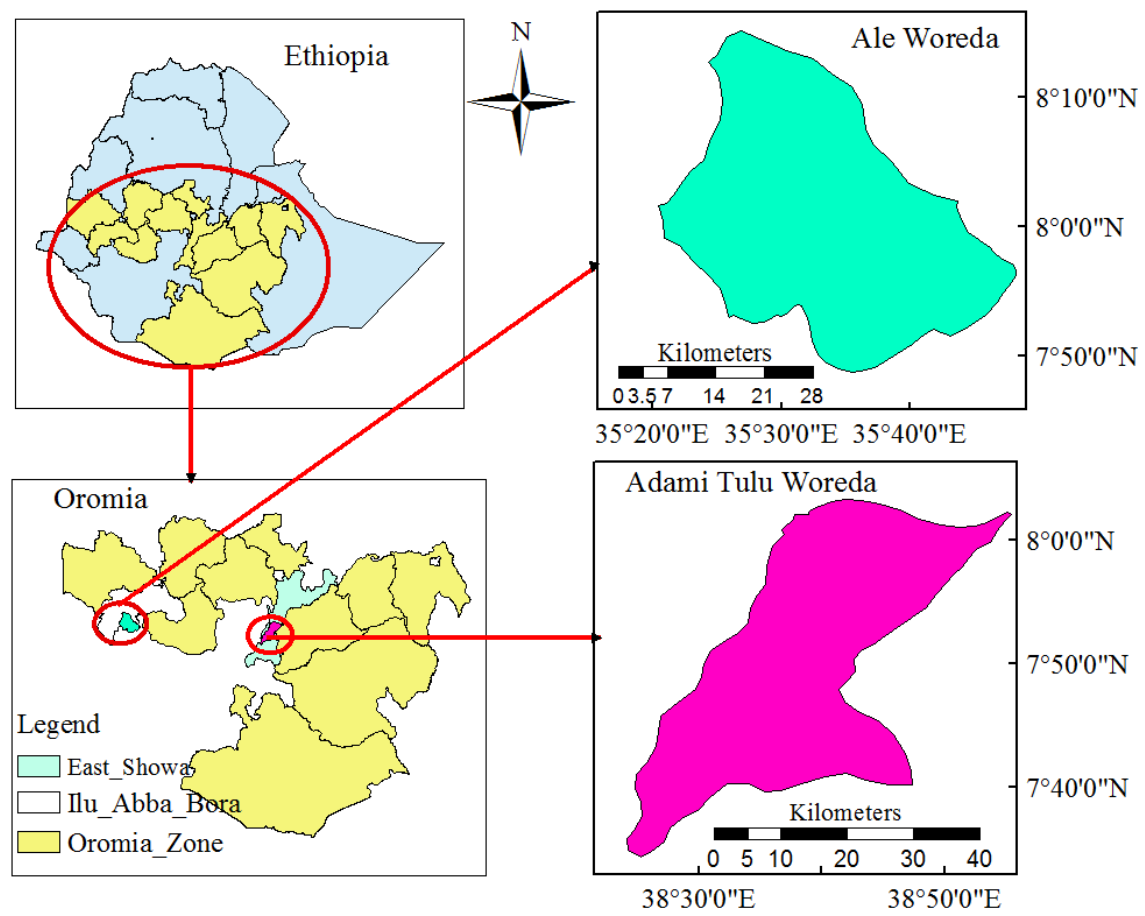

Figure 1. Map of the research locations

\section{Time scale selection}

Standardized precipitation evapotranspiration index (SPEI)-3 month time scale was selected from 1-48 months of time scales to analyze agricultural drought index. SPEI-3 month scale is a short and medium term of soil moisture and provides a seasonal estimate of agricultural drought condition when there is insufficient soil moisture to meet the needs of a particular crop at particular times (WMO, 2012). However, the 3month of drought index may also be misleading in regions where it is normally dry during any given 3-month period. Therefore, to avoid such problem, we selected four main crops growing months from June to September

\section{Data analyses}

\section{Analysis of temperature and precipitation trends}

The non-parametric Mann Kendall test was used to detect monotonically time series trended climatic factors and drought. Its statistical value (S-score) indicates the capacity of the climate system to the long-term change of climatic factors. Mann Kendall statistic value of temperature and precipitation was analyzed using $\mathrm{R}$ - Studio model. It is defined as the sum of the number of positive differences minus the sum of the number of negative differences (Edwards, 1997) and calculated by;

$$
S=\sum_{k=1}^{n-1} \sum_{j=n+k}^{n} \operatorname{sign}\left(Y_{j}-Y_{k}\right)
$$

Where: Sign $\left(Y_{j}-Y_{k}\right)$ is an indicator function that results in the values 1,0 , or -1 according to the significance of $Y_{j}-Y_{k}$, where $j=2,3,4 \ldots$ and $k=1$, $2,3 \ldots$ then the functions are calculated as follows:

$$
\operatorname{sign}(\theta)=\left\{\begin{aligned}
1 & \text { if } \theta>0 \\
0 & \text { if } \theta=0 \\
-1 & \text { if } \theta<0
\end{aligned}\right.
$$

Where: $\operatorname{sign}(\theta)=\operatorname{sign}\left(Y_{j}-Y_{k}\right)$

A normalized statistical significance test (Zscore test) was computed to check the statistical significance of the increasing or decreasing trends of temperature and precipitation at $0.05\left(Z_{-} \alpha / 2=\right.$ \pm 1.96 ) significance levels.

\section{Analyses of drought indices}

Potential evapotranspiration, water balance and SPEI were analyzed using $\mathrm{R}$ software. Drought indices such as severity, duration and intensity were analyzed using the outputs from SPEI analyses. The SPEI allows comparison of 
drought severity through time and space and shows better correlation with the yields of crop production which is strongly affected by soil moisture. It is statistically robust and easily calculated and has comprehensible calculation procedure (Beguer, 2014). The crucial advantage of SPEI over other drought indices is that it considers the effect of temperature on drought that is able to identify different types of drought with the context of global warming (Funk et al., 2018). It is designed to take into account both precipitation and potential evapotranspiration in the determining drought events.

Potential evapotranspiration was calculated using equation of Hargreaves and Allen (2003). This equation can use maximum and minimum temperatures with specific values of altitudes of the two sites of study. We calculated water balance $(\omega)$ as the difference between precipitation and potential evapotranspiration. The difference is the water surplus or deficit for the analyzed months and is calculated using the equation of Vicente-Serrano et al. (2010).

$$
\omega=P R C P-P E T
$$

Where: $\omega$ is water balance, PRCP is precipitation and PET is potential evapotranspiration.

Finally, SPEI was calculated using R-Software and drought was defined when the values of SPEI fall below zero i.e. the negative SPEI values are considered drought and positive SPEI values are non-drought. Duration is the period length, in which the SPEI is continuous negative and it is expressed in terms of consecutive months with no rainfall, and the severity of drought was calculated as:

$$
\text { Severity }(\Sigma)=\sum_{i=1}^{D} S P E I_{i}
$$

Where: D is dry duration, in which SPEI is continuous negative.

The intensity of drought is measured by dividing the drought severity to its duration.

$$
\text { Intensity }(I)=\frac{\sum}{D}
$$

Based on the procedure proposed by Edwards (1997), the values of SPEI are classified into seven categories, from dry to wet conditions. 'Positive' SPEI-3 value designates greater than zero and 'negative' value designates less than zero (Table 1).

Table 1. The classification of drought intensity based on SPEI-3 value

\begin{tabular}{lcl}
\hline Anomaly & $\begin{array}{c}\text { Range of SPEI } \\
\text { values }\end{array}$ & \multicolumn{1}{c}{ Category } \\
\hline Positive & $2<$ SPEI $\leq$ Max & Extremely wet \\
& $1.5<$ SPEI $\leq 2$ & Very wet \\
& $1<$ SPEI $\leq 1.5$ & Moderate \\
\hline None & $-1<$ SPEI $\leq 1$ & Normal \\
\hline Negative & $-1.5<$ SPEI $\leq-1$ & Moderately dry \\
& $-2<$ SPEI $\leq-1.5$ & Severely dry \\
Min $<$ SPEI $\leq-2$ & Extremely dry \\
\hline
\end{tabular}

Source: Edwards (1997)

The variability and trends of drought were then analyzed using Mann Kendall trend test, after verifying significant change of agricultural droughts. Finally, the significant differences in changing the climatic variables and drought indices were done by comparing the two climatic zones using t test of SPSS version 20.

\section{RESULTS AND DISCUSSION}

\section{Trend analyses of seasonal temperature and precipitation}

\section{Maximum temperature}

Maximum temperature significantly increased at shocking rate, especially over the moist-cool zone $(\mathrm{P}<0.01)$. The Mann Kendall trend test $(\mathrm{S})$ results revealed that the maximum temperatures of the two Woredas significantly increased at Pvalues of 0.01 and 0.04 , for Ale and Adami, respectively. However, stronger change in maximum temperature was observed in Ale than in Adami Tulu Woreda. The intensive change of the Earth's surface temperature is primarily due to the increase of greenhouse gas concentration from human activities (Devaraju et al., 2015). Deforestation and forest degradation are the principal human activities that decrease precipitation and evaporation which results in the increase of surface temperature over the deforested area (Zhang et al., 1996). The summer temperature also increases when the sun passes directly above the equator because of the tilt of the Earth (De Pontieu et al., 2014). Consistent to this study, Asfaw et al. (2018) reported that maximum and minimum temperature tended to be 
significantly increasing trends from 1901 to 2014 in North Central Ethiopia. An increasing maximum temperature during crop growing seasons in Ethiopia was also reported by Suryabhagavan (2017) which is the real concern for agricultural activities.

\section{Minimum temperature}

Unlike maximum temperature, minimum temperature did not change at appreciable level in the Adami Tulu, but it significantly increased at $\mathrm{p}$ value $=0.02$ in the Ale Woreda $($ Table 2$)$.

Table 2. Trend analyses of climatic variables in June-September (1981-2016)

\begin{tabular}{lrcrrcc}
\hline \multirow{2}{*}{ Variables } & \multicolumn{3}{c}{ Ale } & \multicolumn{3}{c}{ Adami Tulu } \\
\cline { 2 - 7 } & S-score & Sen's slop & P-value & S-score & Sen's slop & P-value \\
\hline Maximum temperature (JJAS) & 222.75 & 0.01 & $0.01^{* *}$ & 150.25 & 0.04 & $0.04^{*}$ \\
Minimum temperature (JJAS) & 161.50 & 0.02 & $0.02^{*}$ & 119.50 & 0.06 & $0.07^{\text {ns }}$ \\
Precipitation (JJAS) & -168.50 & -3.65 & $0.03^{*}$ & 17.50 & 1.49 & $0.78^{\text {ns }}$ \\
\hline
\end{tabular}

Note: ** and *statistically changing trend at $\alpha=0.01$ and 0.05 respectively; ns $=$ non-significant

\section{Precipitation}

Similar to temperatures, the precipitation of Ale Woreda significantly decreased $(\mathrm{P}<0.05)$, but no significant change was observed in the Adami Tulu Woreda. There is high confidence that increased temperatures will lead to more precipitation falling as increase of an evapotranspiration. Many studies reported that the reduction of vegetation triggers a significant reduction in precipitation amounts due to a modification of the evapotranspiration regime and consequently of the regional water cycle (Hasler et al., 2009; Bathiany et al., 2010). Snyder (2010) reported that deforestation to bare land results in the decrease of precipitation of $467 \pm 102 \mathrm{~mm}$ $\mathrm{yr}^{-1}$ for loss of forest and $314 \pm 117 \mathrm{~mm} \mathrm{yr}^{-1}$ for loss of shrub lands.

\section{Agricultural drought analysis}

Three-month time scale of Standardized Precipitation Evapotranspiration (SPEI3) was computed for the moist-cool and moist-warm ecoclimatic zones (Figure 2). The outputs of the SPEI values were characterized for frequency, severity, duration, intensity and trends of agricultural indices.

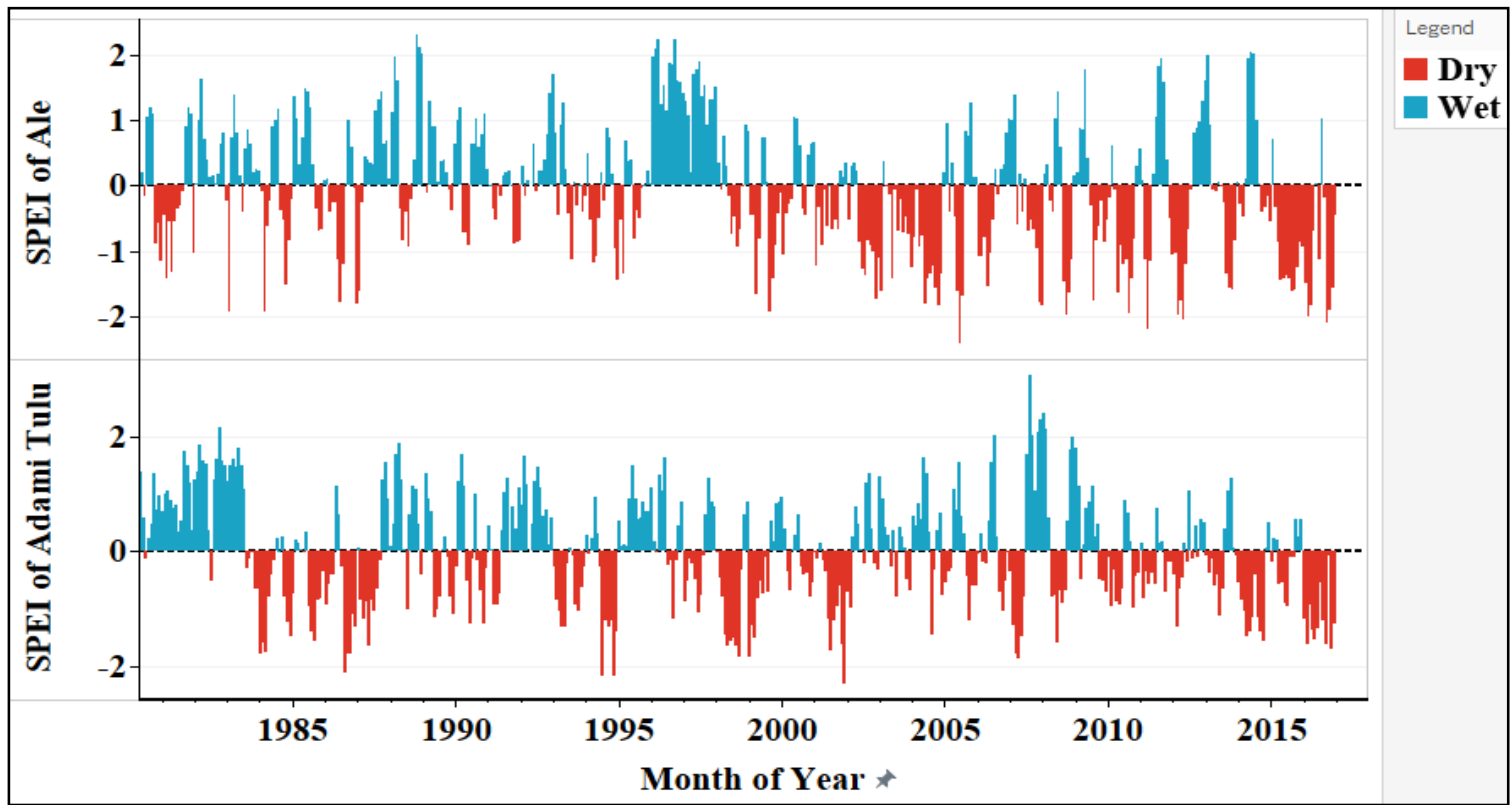

Figure 2. The SPEI-3 of Ale and Adami Tulu Wordas from 1981 to 2016.

Red color shows details about drought and blue indicates wet condition of the two research locations. 
Frequency, severity, duration and intensity of drought

Frequency

The number of drought events occurring since 1981 year widely-ranged in time and spaces. It happened 12 times in 31 years in the Ale and 17 times in 30 years in Adami Tulu (Table 3). It occurred every three and two years for Ale and Adami Tulu Woreda, respectively. The frequent drought events dramatically increase the number of people at risk in Ethiopia (Funk et al., 2012). In the country, one drought event lowers GDP by 7 to $10 \%$ and increases poverty by 12 to $14 \%$ (Makombe et al., 2017).

Table 3. Duration, severity and intensity of agricultural drought

\begin{tabular}{lccccll}
\hline District & Year & Severity & Duration & Intensity & Category & Description \\
\hline Ale & 1986 & -3.00 & 2 & -1.50 & Sever dry & June and July \\
& 1993 & -1.12 & 1 & -1.12 & Moderate dry & July \\
& 1999 & -3.34 & 2 & -1.67 & Sever dry & July and September \\
& 2002 & -2.65 & 2 & -1.32 & Moderate & June-July \\
& 2004 & -5.56 & 4 & -1.39 & Moderate & June-September \\
& 2005 & -4.11 & 2 & -2.05 & Extremely & June and July \\
& 2008 & -3.45 & 2 & -1.72 & Sever dry & August and September \\
& 2009 & -1.76 & 1 & -1.76 & Sever dry & July \\
& 2010 & -5.68 & 4 & -1.42 & Moderate dry & June-September \\
& 2013 & -2.91 & 2 & -1.45 & Moderate dry & August and September \\
& 2015 & -4.53 & 3 & -1.51 & Sever dry & June, August and September \\
& 2016 & -3.84 & 2 & -1.92 & Sever dry & June and July \\
\hline Adam6-2016 Tulu & 12 & -41.95 & 27 & -1.5537 & Sever dry & June-September \\
& 1985 & -3.00 & 2 & -1.50 & Sever dry & August and September \\
& 1986 & -3.90 & 2 & -1.95 & Sever dry & August and September \\
& 1987 & -1.04 & 1 & -1.04 & Moderate dry & July \\
& 1988 & -1.02 & 1 & -1.02 & Moderate dry & July \\
& 1989 & -1.02 & 1 & -1.02 & Moderate dry & June \\
& 1990 & -1.27 & 1 & -1.27 & Moderate dry & June \\
& 1994 & -4.73 & 3 & -1.58 & Sever dry & July-September \\
& 1996 & -1.18 & 1 & -1.18 & Moderate dry & September \\
& 1997 & -1.09 & 1 & -1.09 & Moderate dry & June \\
1998 & -6.58 & 4 & -1.64 & Sever dry & June-September \\
2001 & -4.14 & 3 & -1.38 & Moderate dry & July-August \\
2004 & -1.47 & 1 & -1.47 & Moderate dry & August \\
2008 & -1.61 & 1 & -1.61 & Sever dry & June \\
\hline 2013 & -1.13 & 1 & -1.13 & Moderate dry & June \\
& 2014 & -3.70 & 3 & -1.23 & Moderate dry & June, August, September \\
& 2015 & -4.62 & 3 & -1.54 & Sever dry & June, August, September \\
2016 & -6.72 & 4 & -1.68 & Sever dry & June-September \\
\hline 19 & -48.22 & 33 & -1.4612 & Moderate dry & June-September \\
\hline & & & & & &
\end{tabular}

\section{Severity}

The harshness of agricultural drought fluctuated, going up and down, in both sites during the time series. The total amounts of severity indices were -41.95 and -48.22 for Ale and Adami Tulu Woreda, respectively. The most severe drought indices with -16.96 and -16.17 bottom values were recorded in the 2010 to 2016 for Ale and Adami Tulu. Increasing severity of drought might be associated to global temperature increase. The strong role of temperature on the drought severity is increasing heat wave, in which extreme high temperature dramatically increases evapo-transpiration and correspondingly aggravates drought stress (Rebetez et al., 2009) and enhances plant mortality under precipitation shortages (Hicke and Zeppel, 2013).

\section{Duration}

The length of drought occurrence is one of the most characteristics of drought that can be 
calculated by using outputs of SPEI analysis. The total time covered by incidences of agricultural drought was 27 and 33 months for Ale and Adami Tulu Woreda, respectively. The longest durations of drought events, four months, were recorded in the 2004 and 2016 at Ale, and in the 1998 and 2016 at Adami Tulu. The other five events with three-month-long duration happened in 2014 at Ale district and the others four events were observed in 1994, 2001, 2014 and 2015 years in Adami Tulu (Table 3). Recent study revealed that global warming increases the duration of drought events. Liu et al. (2018) stated that the projected 1.5 to $2^{\circ} \mathrm{C}$ increase of global warming increases in drought durations from 2.9 to 3.2 months.

However, the drought events during 1992, 1998, 2004, 2005, 2010, 2014 and 2016 might be related to the El Nino listed by NOAA climate prediction center (2012). USAID AKLDP (2015) also stated that the changes in the Pacific Ocean temperature creates unusual weather patterns, such as drought or excessive rainfall and storms in Ethiopia, Somalia and Djibouti.

\section{Intensity}

It is the most important parameters to quantify the strength of the agricultural drought. The average intensity of drought recorded in the Ale was -1.55 drought spell. The highest drought intensity was observed in the Ale Woreda in 2005 for June and July with -2.05 lowest SPEI values and followed by -1.92 drought spell, which was recorded in the 2016. According to Edward (1997), the lower values of drought indices indicate the higher intensity of drought and thus, drought intensity values -2.05 and -1.92 were labeled as exterme, and severe dry, respectively. The other five drought intensity levels were considered severe dry and four were moderately dry. Similarly, the average drought intensity level of Adami Tulu Woreda was -1.46 index values. Its highest intensity level was recorded in 2016 with lowest value of -1.68 index. Seven and ten distinct levels of agricultural droght intensities were put under severe and moderate dry in Adami Tulu woreda (Table 3).

The spatial distribution of agricultural drought intensity was analyzed to identify the scope of agricultural drought at the two sites. Results showed that the intensity of agricultural drought covered wider areas in Ale Woreda as compared to drought intensity coverage in the Adami Tulu Woreda. Drought intensity location AL1, AL2 and AL3 were found to be severe dry (greater than $1.5)$ and in the other location, AL4, was observed wet conation (Figure 3A). The spatial distribution of drought intensity in Adami Tulu Woreda covered only for the most part of lacation BL4. BL2 and BL3 were observed very wet whereas BL1 was normal (Figure 3B).

The highest drought intensity of Ale Woreda might be related to the effects of temperature increase at the region. The increasing temperature upsurges heat wave, in which extreme high temperatures dramatically increase evapotranspiration and correspondingly aggravate drought stress (Rebetez et al., 2009). The drought in 2004-2005, 2010, 2015 and 2016 might be related to El Nino events of 2004-2005, 20062007, 2009-2010, 2014-2016 listed by Colombia University (2015).

Several studies reported that the deficiency of water, especially during critical sowing, flowering and ripening period decreases crop yields and increases food insecurity (Lamaoui et al., 2018). From an agriculture point of view, rainfall during June and July is very critical for crop sowings, rainfall during July and August is very critical for plant physiological growth and rainfall in August is vital for the growing, flowering and ripening of different crops. Rainfall pattern in August and September plays a greater role in the occurrence of agricultural drought (Zargar et al., 2011). The planting onset of most staple crops like maize, sorghum, millet and durum wheat sowing starts on May and ends on July 15, and the crop growth of flowering and ripening period is between June 1 and September 31 in the eastern parts of Oromia (CSA, 2016). However, the value of drought index less than -1.5 indicates a very small amount of rainfall that is certainly not enough to maintain enough soil moisture for agriculture (Kumar et al., 2015). The stresses resulting from drought during the above critical times can influence the normal physiological process of the plant and cause damage, as the result of abnormal metabolism and may reduce growth, plant death or plant development (Fathi and Tari, 2016). The shoot and root biomass of the crop plants are higher in moist soil than in dry soil (Xue et al., 2017). 


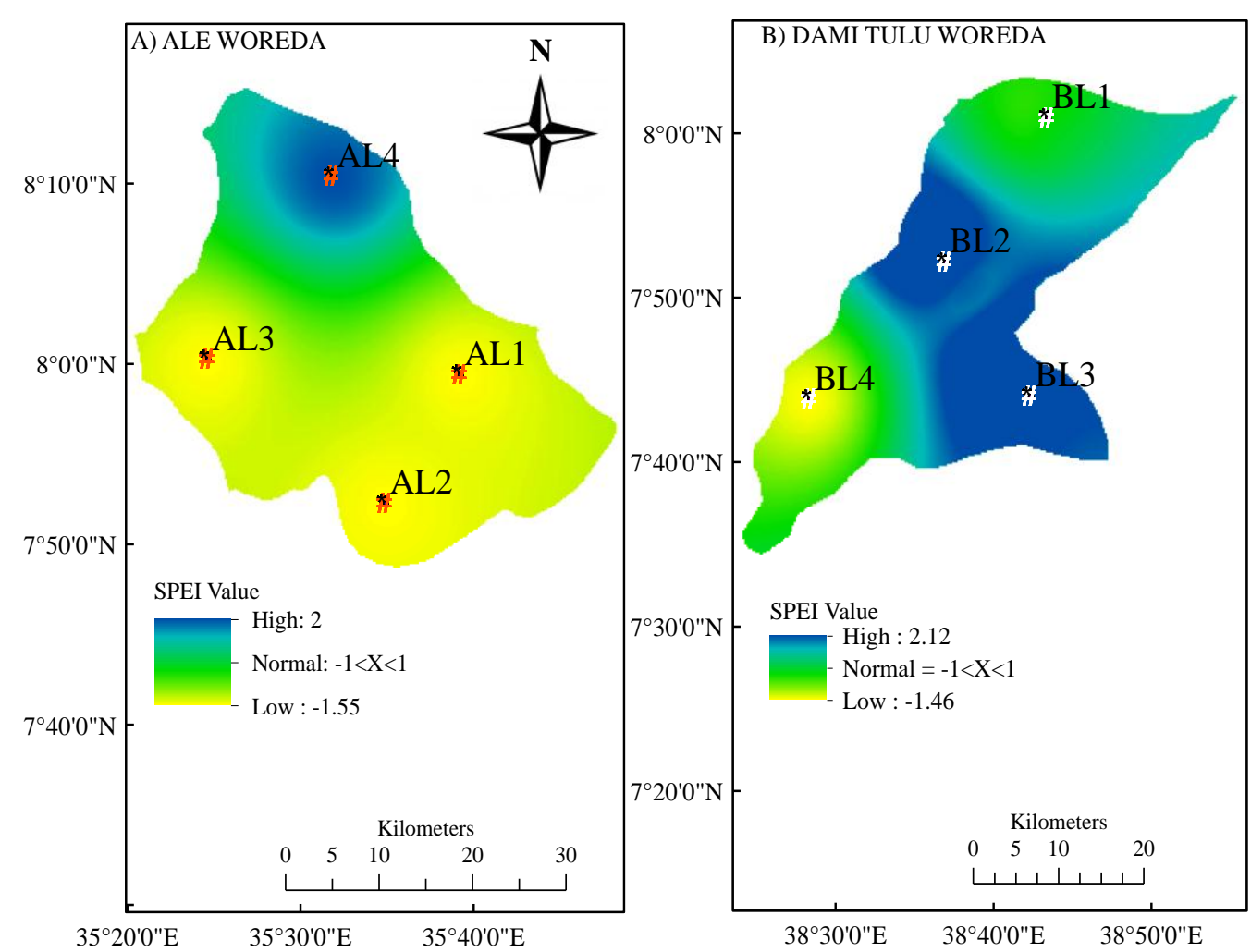

Figure 3. Spatial distribution of agricultural drought intensity

\section{Analysis of drought variability and trends}

Results of Mann Kendall trend analysis indicated that agricultural drought was wideranged by time and spaces. The S-values of drought intensity in the Ale Woreda significantly increased $(\mathrm{P}<0.05)$ whereas there was not any appreciable change in drought intensity observed in Adami Tulu Woreda. The P-values of drought intensity increment in the Ale Woreda were 0.03 , 0.01 and 0.01 for July, August and September, respectively. Their rates of increment per a year, in percent, were 3.83, 4.16 and 4.96 for July, August and September (Table 4). The significant change of drought indices during the definite months might be associated to the change of climatic factors. Peterson (2018) reported that climate variability and shifting trends produce severe droughts, and the fragile food insecure populations may rapidly face severe food crises as supplies drop, prices rise and household incomes decline.

Table 4. Analysis of trends of agricultural drought intensity

\begin{tabular}{ccccccc}
\hline \multirow{2}{*}{ Month } & \multicolumn{3}{c}{ Ale } & \multicolumn{3}{c}{ Adami Tulu } \\
\cline { 2 - 7 } & S-score & Sen's slop & P-value & S-score & Sen's slop & P-value \\
\hline June & -84 & 2.31 & $0.30^{\text {ns }}$ & -104 & 1.97 & $0.16^{\text {ns }}$ \\
July & -166 & 3.83 & $0.03^{* *}$ & 54 & 1.12 & $0.49^{\text {ns }}$ \\
August & -204 & 4.16 & $0.01^{* *}$ & -78 & 1.78 & $0.31^{\text {ns }}$ \\
Sept & -218 & 4.96 & $0.01^{* *}$ & -76 & 1.38 & $0.33^{\text {ns }}$ \\
JJAS & -212 & 3.64 & $0.01^{* *}$ & -72 & 1.07 & $0.35^{\text {ns }}$ \\
\hline
\end{tabular}

Note: $* *$ and $*$ statistically decreasing trend at $\alpha=0.01$ and 0.05 significant levels, respectively; ns $=$ nonsignificant; JJAS indicates June, July, August and September

\section{Comparative analysis of climate change and drought indices}

The mean values of $\mathrm{S}$-scores from trend analyses were compared by using paired samples t test, in which eco-climatic zone, temperature, precipitation and drought strongly changed. Results showed that the means of S-score in maximum temperature, precipitation and drought 
indices of two eco-climatic zone were significantly different $(\mathrm{P}<0.05)$. Nonetheless, there was not any appreciable mean of minimum temperature difference between the two zones.
This indicates that the changes of the variables in Ale Woreda were significantly stronger than the corresponding variables in the Adami Tulu Woreda (Table 5).

Table 5. Mean comparison of climatic variables and drought over the moist-cool and moist-warm climatic zones

\begin{tabular}{cccccc}
\hline \multirow{2}{*}{ Climate variables } & \multicolumn{2}{c}{ Mean of S-score } & \multirow{2}{*}{ Difference } & \multirow{2}{*}{ Stdev } & \multirow{2}{*}{ P-value } \\
\cline { 2 - 4 } & \multicolumn{1}{c}{ Ale } & Adami Tulu & & \\
\hline Maximum temperature (JJAS) & 222.75 & 150.25 & 72.0 & 35.18 & $0.035^{*}$ \\
Minimum temperature (JJAS) & 161.25 & 119.00 & 42.5 & 37.62 & $0.11^{\text {ns }}$ \\
Precipitation (JJAS) & -168.50 & 17.50 & -186.0 & 92.58 & $0.03^{*}$ \\
Drought indices (JJAS) & -212.00 & -72.00 & -140.0 & 59.14 & $0.04^{*}$ \\
\hline
\end{tabular}

Note: **and* statistically decreasing trend at $\alpha=0.01$ and 0.05 significant levels, respectively; ns $=$ nonsignificant; JJAS indicates June, July, August and September

The stronger change of the maximum temperature and precipitation in Ale might be due to the ecological change through deforestation. The forest ecological change is likely to affect the climate through both biochemical and biophysical processes and contribute to climate change (Alig, 2011). An anthropogenic land cover changes affect local, regional and global climate through biophysical variations of land cover that arbitrates evapotranspiration (Perugini et al., 2017). The maximum increase enhances hydrological cycle and evapotranspiration and increases droughts in general, and meteorological and agricultural drought are more influenced by climate change in particular (Lee et al., 2017).

\section{CONCLUSIONS}

This work synthesized results of observational studies, focusing on agricultural drought due to temperature and precipitation changes in the different climatic zones. Results indicated that the changes in maximum and minimum temperatures and precipitation were more pronounced in the moist-cool climatic zone than in moist-warm climatic zone. The changes of climatic variables aggravated agricultural drought in both zones, but its strength and distribution were more pronounced in the Ale than in Adami Tulu Woreda. The study confirmed that Ethiopian moist-cool eco-climatic zones rapidly tracked toward severe climatic shocks because the change in climatic variables was more intensified over the moist-cool than over moist-warm climatic zone. Therefore, developing drought-tolerant crops and soil water conservation shall be done for coping up with future drought challenges in the moist cool climatic zone.

\section{REFERENCES}

Alig, J. R. (2011). Effects of Climate Change on Natural Resources and Communities: A Compendium of Briefing Papers. Birds and Climate Change, (March), 169. Retrieved from http://www.researchgate.net/publication /225752488_Socio-economic_impacts_of_ climate_change_on_rural_United_States/file/ 79e4150a559a5e1072.pdf

Arndt, C., Chinowsky, P., Robinson, S., Strzepek, K., Tarp, F., \& Thurlow, J. (2012). Economic Development under Climate Change, Review of Development Economics, 16(3), 369-377. https://doi.org/10.1111/j.1467-9361.2012.006 68.x

Asfaw, A., Simane, B., Bantider, A., \& Hassen, A. (2018). Determinants in the adoption of climate change adaptation strategies: evidence from rainfed-dependent smallholder farmers in north-central Ethiopia (Woleka sub-basin). Environment, Development and Sustainability, 1-31. https://doi.org/10.1007/s10668-018-015 $0-\mathrm{y}$

Bathiany, S., Claussen, M., Brovkin, V., Raddatz, T., \& Gayler, V. (2010). Combined biogeo physical and biogeochemical effects of largescale forest cover changes in the MPI earth system model. Biogeosciences, 7(5), 13831399. https://doi.org/10.5194/bg-7-1383-2010

Beguer, S. (2014). Standardized precipitation evapotranspiration index (SPEI) revisited: 
parameter fitting, evapotranspiration models , tools, datasets and drought monitoring. International Journal of Climatology, 34(10), 3001-3023. https://doi.org/10.1002/joc.3887

Conway, D., \& Schipper, E. L. F. (2011). Adaptation to climate change in Africa: Challenges and opportunities identified from Ethiopia. Global Environmental Change, 21(1), 227-237. https://doi.org/10.1016/ j.gloenvcha.2010.07.013

Colombia University. (2015). El Niño 2015 Conference Report 1, 1-74. Retrieved from https://iri.columbia.edu/wp-content/uploads/ 2016/04/El-Nino-2015-Conference-Report. pdf

CSA. (2016). Agricultural Sample Survey 2015/16 (2008 E.C). Volume I-Report on Area and Production of Major Crops. Statistical Buleletin 584. Addis Ababa, Central Statstical Agency. Statistical Bulletin, I, 121.

De Pontieu, B., Title, A. M., Lemen, J. R., Kushner, G. D., Akin, D. J., Allard, B., ... Waltham, N. (2014). The Interface Region Imaging Spectrograph (IRIS). Solar Physics, 289(7), 2733-2779. https://doi.org/10.1007/ s11207-014-0485-y

Devaraju, N., Bala, G., \& Modak, A. (2015). Effects of large-scale deforestation on precipitation in the monsoon regions: Remote versus local effects. Proceedings of the National Academy of Sciences, 112(11), 32573262. https://doi.org/10.1073/pnas.14234391 12

Edwards, D. C. (1997). Characteristics of 20th century drought in the United States at multiple time scales. Colorado State University. Libraries. Retrieved from https:// mountainscholar.org/handle/10217/170176

Ethiopian Treasures. (n.d.). Climate. Retrieved July 25, 2019, from http://www.ethiopian treasures.co.uk/pages/climate.htm

FAO. (2012). The State of Food and Agriculture2012: Investing in Agriculture for a Better Future. Rome: FAO. Retrieved from http://www.fao.org/3/a-i3028e.pdf

Fathi, A., \& Tari, D. B. (2016). Effect of Drought Stress and its Mechanism in Plants. International Journal of Life Sciences, 10(1),
1-6. https://doi.org/10.3126/ijls.v10i1.14509

Funk, C., Harrison, L., Shukla, S., Pomposi, C., Galu, G., Korecha, D., ... Verdin, J. (2018). Examining the role of unusually warm IndoPacific sea-surface temperatures in recent African droughts. Quarterly Journal of the Royal Meteorological Society, 144(S1), 360383. https://doi.org/10.1002/qj.3266

Funk, C., Rowland, J., Eilerts, G., \& White, L.,. (2012). A Climate Trend Analysis of Uganda. U.S. Geological Survey Fact Sheet, 2012 3053, 4 p.. https://doi.org/10.3133/fs20123062

Gebreegziabher, Z., Stage, J., Mekonnen, A., \& Alemu, A. (2016). Climate change and the Ethiopian economy: a CGE analysis. Environment and Development Economics, 21(2), 205-225. https://doi.org/10.1017/S135 $5770 \times 15000170$

Hargreaves, G. H., \& Allen, R. G. (2003). History and Evaluation of Hargreaves Evapotrans piration Equation. Journal of Irrigation and Drainage Engineering, 129(1), 53-63. https://doi.org/10.1061/(asce)0733-9437(2003 )129:1(53)

Hasler, N., Werth, D., \& Avissar, R. (2009). Effects of tropical deforestation on global hydroclimate: A multimodel ensemble analysis. Journal of Climate, 22(5), 1124 1141. https://doi.org/10.1175/2008JCLI2157. 1

Hicke, J. A., \& Zeppel, M. J. B. (2013). ClimateDriven Tree Mortality: Insights from The Piñon Pine Die-Off in the United States. New Phytologist., 200(2), 301-303. https://doi.org/ 10.1111/nph.12464

Kedir, G. O. N., Abagodu, R., Ambelu, B. D. W., \& Magut, F. O. O. M. (2018). Bellmon Analysis on Crop Availability and Market Study in Ethiopia, (January).

Kumar, M. N., Murthy, C.S., Sai, M. V. R. S., \& Roy, P. S. (2015). On the use of Standardized Precipitation Index (SPI)for drought intensity assessment. Retrieved from https://arxiv.org/ pdf/1509.04808

Lamaoui, M., Jemo, M., Datla, R., \& Bekkaoui, F. (2018). Heat and Drought Stresses in Crops and Approaches for Their Mitigation. Frontiers in Chemistry, 6, 26. https://doi.org/ 


\subsection{9/fchem.2018.00026}

Lee, S.-H., Yoo, S.-H., Choi, J.-Y., \& Bae, S. (2017). Assessment of the Impact of Climate Change on Drought Characteristics in the Hwanghae Plain, North Korea Using Time Series SPI and SPEI: 1981-2100. Water (Switzerland), 9(8), 579. https://doi.org/10. 3390/w9080579

Liu, W., Sun, F., Ho Lim, W., Zhang, J., Wang, H., Shiogama, H., \& Zhang, Y. (2018). Global drought and severe drought-Affected populations in 1.5 and $2{ }^{\circ} \mathrm{C}$ warmer worlds. Earth System Dynamics, 9(1), 267-283. https://doi.org/10.5194/esd-9-267-2018

Mahoo, H., Radeny, M., Kinyangi, J., Cramer, L., \& Eds. (2013). Climate change vulnerability and risk assessment of agriculture and food security in Ethiopia: Which way forward? CCAFS Working Paper No. 59. CCAFS Working Paper No. 59. Copenhagen, Denmark: CGIAR Research Program on Climate Change, Agriculture and Food Security (CCAFS). Retrieved from https://hdl. handle.net/10568/35082

Makombe, G., Namara, R. E., Awulachew, S. B., Hagos, F., Ayana, M., \& Kanjere, M. (2017). An analysis of the productivity and technical efficiency of smallholder irrigation in Ethiopia. Water SA, 43(1), 48-57. https:// doi.org/10.4314/wsa.v43i1.08

NOAA- CLimate prediction center. (2012). Climate Prediction Center-Warm Episodes. Retrieved July 25, 2019, from https://origin. cpc.ncep.noaa.gov/products/analysis_monitor ing/ensostuff/ONI_v5.php

erugini, L., Caporaso, L., Marconi, S., Cescatti, A., Quesada, B., de Noblet-Ducoudré, N., ... Arneth, A. (2017). Biophysical effects on temperature and precipitation due to land cover change. Environmental Research Letters, 12(5), 053002. https://doi.org/10.10 88/1748-9326/aa6b3f

Peterson, P. (2018). Satellite Rainfall Products : Joel Michaelsen' s Humanitarian Legacy CHIRPS. NOAA's 43rd Climate Diagnostics \& Prediction Workshop, UCSB, Santa Barbara, Ca. Retrieved from https://www.cpc. ncep.noaa.gov/products/outreach/CDPW/43/o ral sessions/presentations/wed/CDPW2018- pete-peterson.pdf

Rebetez, M., Dupont, O., \& Giroud, M. 2009. An Analysis of The July 2006 Heatwave Extent in Europe Compared to The Record Year of 2003. Theoretical and Applied Climatology. 95(1-2), 1-7. https://doi.org/10.1007/s00704007-0370-9

Snyder, P. K. (2010). The influence of tropical deforestation on the Northern Hemisphere climate by atmospheric teleconnections. Earth Interactions, 14(4), 1-34. https://doi.org/10. 1175/2010EI280.1

Suryabhagavan, K. V. (2017). GIS-based climate variability and drought characterization in Ethiopia over three decades. Weather and Climate Extremes, 15, 11-23. https://doi.org/ 10.1016/j.wace.2016.11.005

Svoboda, M. D., \& Fuchs, B. A. (2017). Handbook of drought indicators and indices. Drought and Water Crises: Integrating Science, Management, and Policy, Second Edition (Second Edi). Boca Raton: CRC Press. https://doi.org/10.1201/b22009

United Nations, \& Nations, U. (2011). The Great Green Technological Transformation. World Economic and Social Survey 2011. Retrieved from https://www.un.org/en/development/de sa/policy/wess/wess_current/2011wess.pdf

USAID Ethiopia Agriculture Knowledge, Learning, Documentation and Policy (AKLDP). (2015). El Niño in Ethiopia: Uncertainties, impacts and decision-making. Agriculture Knowledge, Learning Documen tation and Policy (AKLDP) Project, (September), 2. Retrieved from https:// www.google.com/url?sa $=t \& r c t=j \& q=\&$ esrc $=s$ $\&$ source $=$ web $\& c d=1 \& c a d=$ rja $\&$ uact $=8 \& v e d=$ 2ahUKEwjAtp71p9zjAhUJMY8KHckjDmIQ FjAAegQIAhAC\&url=https\%3A\%2F\%2Fagr i-learning-ethiopia.org\%2Fwp-content $\% 2 \mathrm{Fup}$ loads\%2F2015\%2F09\%2FAKLDP-El-Ninobrief-Sept-2015.pdf\&usg=AOvVaw1Xc6LlF X1A6ZUs-B2mOHQT

Vicente-Serrano, S. M., Beguería, S., \& LópezMoreno, J. I. (2010). A multiscalar drought index sensitive to global warming: The standardized precipitation evapotranspiration index. Journal of Climate, 23(7), 1696-1718. https://doi.org/10.1175/2009JCLI2909.1 
Wang, H., Sun, F., Liu, W., Lim, W. H., Shiogama, H., Zhang, Y., \& Zhang, J. (2018). Global drought and severe drought-affected populations in 1.5 and 2 \&amp;thinsp; ${ }^{\circ} \mathrm{C}$ warmer worlds. Earth System Dynamics, $9(1)$, 267-283. https://doi.org/10.5194/esd-9-2672018

World Meteorological Organization, [WMO]. (2012). WMO 2012 Survey on the Use of Satellite Data. Retrieved from http://www.wmo.int/pages/prog/sat/meetings/ documents/ET-SUP-7_Doc_05_WMO2012 Survey-Presentation.pdf

Xue, R., Shen, Y., \& Marschner, P. (2017). Soil water content during and after plant growth influence nutrient availability and microbial biomass. Journal of Soil Science and Plant Nutrition, 17(3), 702-715. https://doi.org/ $10.4067 / \mathrm{s} 0718-95162017000300012$
Zargar, A., Sadiq, R., Naser, B., \& Khan, F. I. (2011). A review of drought indices. Environmental Reviews, 19(1), 333-349. https ://doi.org/10.1139/a11-013

Zerga, B., \& Mengesha, G. G. (2018). Climate Change in Ethiopia Variability, Impact, Mitigation , and Adaptation Journal of Social Science and Humanities Research. Inter national Journal of Science and Humanities Research, 2(4), 66-84. https://doi.org/10.13 140/RG.2.2.16782.46408

Zhang, H., Henderson-Sellers, A., \& McGuffie, K. (1996). Impacts of Tropical Deforestation. Part I: Process Analysis of Local Climatic Change. Journal of Climate, 9(7), 1497-1517. https://doi.org/10.1175/1520-0442(1996)009< 1497:iotdpi>2.0.co;2 